\title{
Bør vi boikotte faglig samarbeid med Kina?
}

\author{
Mange leger blir ofte invitert til å delta på kinesiske kongresser og publisere artikler i kinesiske tidsskrifter. \\ De fleste invitasjonene ender med et tastetrykk i søppelboksen. Men bør vi ikke stoppe opp og reagere litt \\ mer bevisst og kritisk?
}

Apartheidregimet i Sør-Afrika ble bredt boikottet, og det ble også OL i Moskva i 1980. Burma ble boikottet, og det tok over 20 år før Aung San Suu Kyi kunne hente sin fredspris fordi hun satt i husarrest. Iran blir utsatt for sanksjoner på grunn av landets atomvåpenprogram - eksempelvis får ikke iranske forskere publisere i amerikanske vitenskapelige tidsskrifter (1). Det vakte nylig oppsikt at den britiske fysikeren Stephen Hawking nektet å reise til et møte i Israel. Bakgrunnen er en akademisk boikott av landet på grunn av behandlingen av palestinerne (2). Boikott som virkemiddel brukes, men det vil alltid være uenighet om det er for mye eller for lite, og selvfølgelig om hvor og når.

\section{Hvorfor Kina - nå?}

Det er gått 24 år siden det kinesiske regimet brutalt slo ned fredelige, ubevæpnede demonstranter på Den himmelske freds (!) plass. Det er lite håp om politisk liberalisering, ifølge kinaeksperter. Kina er visstnok det landet $\mathrm{i}$ verden som dømmer flest til døden. De henretter flere enn resten av verden til sammen. Nobels fredspris ble i 2010 tildelt Liu Xiaobo, en fengslet dissident, «for hans langvarige og ikke-voldelige kamp for fundamentale menneskerettigheter i Kina». Bildet av den symboltunge tomme stolen i Oslo Rådhus lar seg ikke lett viske ut. En ting er fengslingen av pristakeren selv, men at ektefellen utsettes for isolasjon og represalier uten lov og dom bryter på det alvorligste med de prinsippene vi setter høyest. Den kinesiske staten har også vært ganske tung på labben i sin reaksjon mot Norge, grensende til boikott på noen områder.
Gir ikke tildelingen av Nobels fredspris oss et særlig ansvar for å si fra når urett blir begått? Våre politikere slår seg ofte på brystet: «Vi konkurrerer over vår egen vektklasse.» Er ikke dette en sak der de bør tas på ordet, og i det minste debattere åpent om hva som er adekvat reaksjon?

For egen del har jeg begynt å sende begrunnede avslag på kinesiske invitasjoner. Medvirkende har vært det faktum at norske forskere støtter «Kina-invitasjonene» ved å figurere som medlemmer på «Advisory Boards», «Scientific Boards» etc. Er det bevisst eller bevisstløst? Nålestikk fra enkeltpersoner kan raskt bli plagsomme nok selv for giganten. Denne saken fortjener etter mitt syn en langt tydeligere debatt og kanskje anbefaling om full faglig boikott. Et minimum burde være at flere begrunner sine avslag. Hva bør vi mene, og hva bør vi gjøre?

Selvfølgelig har kontakt med regimer vi ikke liker også sin verdi, men er den stor nok til at vi fortsatt skal tie og «tåle så inderlig vel den urett som ikke rammer oss selv»? Jeg mener nei, og et høflig og begrunnet «nei takk» til invitasjoner er en «lavterskelreaksjon». En full boikott av faglig samarbeid bør absolutt diskuteres, det burde både Legeforeningen og leger engasjere seg i. Det er ingen stor hemmelighet at mange av våre kolleger sto i fremste rekke og hyllet Kina i 1960- og 70-årene. Hvorfor er dere så tause nå?

\section{Oppsummert}

De tause blir fort medskyldige. Er ikke tiden inne for kraftigere virkemidler - en klar anbefaling om nasjonal og internasjonal boikott av faglig samarbeid? Om ikke full boikott, bør et minimum være å benytte kommende invitasjoner til å tilkjennegi sitt syn. Bør vi ikke aksle Davids trøye mot Goliat?

\section{Ole-Erik Iversen}

ole-erik.iversen@k2.uib.no

Ole-Erik Iversen (f. 1945) er spesialist i fødselshjelp og kvinnesykdommer, overlege ved Kvinneklinikken, Haukeland universitetssykehus og professor ved Det medisinsk-odontologiske fakultet, Universitetet i Bergen.

Forfatter har fylt ut ICMJE-skjemaet og oppgir følgende interessekonflikter: Han er medlem av Mercks Scientific Advisory Committee for 2. generasjons HPV-vaksiner. Han har mottatt foredragshonorar fra flere firmaer om forskjellige temaer.

\section{Litteratur \\ 1. Marshall E. Scientific journals adapt to new U.S. trade sanctions on Iran. Science 3.5.2013. http://news.sciencemag.org/scienceinsider/2013/ 05/scientific-journals-adapt-to-new.html (17.6.2013). \\ 2. Cressey D. Hawking decision fuels Israel debate. Nature 14.5.2013. www.nature.com/news/ hawking-decision-fuels-israel-debate-1.12986 (17.6.2013).}

Mottatt 13.6. 2013, første revisjon innsendt 17.6. 2013, godkjent 17.6. 2013. Medisinsk redaktør Erlend Hem.

Publisert først på nett. 